\title{
Pengaruh Produk Domestik Bruto, Ekspor Dan Kurs Terhadap Cadangan Devisa Di Indonesia
}

\author{
Fuji Astuty \\ Prodi Manajemen Universitas Prima Indonesia \\ Email : fujiastuty424@gmail.com
}

Received: 21 Desember 2020, 2020; Accepted: 23 Desember 2020; Published: 25 Desember, 2020

\begin{abstract}
Abstrak
Penelitian ini memliki tujuan untuk menganalisis pengaruh produk domestik bruto, ekspor dan kurs terhadap cadangan devisa di Indonesia. Penelitian ini berbentuk kuantitatif yang didasarkan pada data kuantitatif dan bersifat asosiatif untuk melihat hubungan antar variabel atau lebih. Data yang digunakan adalah data time series dari tahun 2001 hingga tahun 2018 dengan menggunakan Eviews 9.0. Dan bersumber dari Bank Indonesia, Badan Pusat Statistik dan Federal Reserve Bank of St. Louis. Penelitian ini menggunakan teknik analisis data adalah analisis linear berganda. Hasil penelitian menunjukkan bahwa variabel produk domestik bruto, ekspor dan kurs berpengaruh positif dan signifikan terhadap cadangan devisa Indonesia. Nilai R-squared dalam penelitian ini sebesar 95.36 menunjukkan bahwa sebesar $95.36 \%$ variasi variabel cadangan devisa yang dapat dijelaskan oleh variabel produk domestik bruto, kurs dan ekspor, sedangkan sisanya $4.64 \%$ dijelaskan oleh variabel lain di luar dari model penelitian ini.
\end{abstract}

Kata kunci : Cadangan Devisa, Ekspor, Kurs, Produk Domestik Bruto

\begin{abstract}
This study aims to analyze the effect of gross domestic product, exports and exchange rate on foreign exchange reserves in Indonesia. This research is in the form of quantitative based on quantitative data and is associative to see the relationship between variables or more. The data used is time series data from 2001 to 2018 using Eviews 9.0. And sourced from Bank Indonesia, the Central Bureau of statistics and the Federal Reserve Bank of St. Louis. This research uses data analysis technique is multiple linear analysis. The results showed that the variables of gross domestic product, exports and exchange rates have a positive and significant effect on Indonesia's foreign exchange reserve. The R-square value in this study is 95.36 , indicating that $95,36 \%$ of the variation in foreign exchange reserves can be explained by the gross domestic product, exchange rates and exports, while the remaining $4.64 \%$ is explained by other variables outside of this research model.
\end{abstract}

Keyword : Foreign Exchange Reserves, Exports, Exchange Rates, Gross Domestic Product, 


\section{PENDAHULUAN}

Indonesia adalah salah satu negara berkembang sehingga Indonesia melakukan banyak pembangunan di segala bidang supaya kesejahteraan masyarakat mengalami peningkatan. Cadangan devisa merupakan salah satu sumber yang sangat penting dalam pendanaan untuk melaksanakan pembangunan nasional bagi Indonesia. Posisi saldo cadangan devisa menunjukkan seberapa besar suatu negara dapat melakukan perdagangan internasional serta kuat lemahnya perekonomian suatu negara. Dengan demikian semakin besar cadangan suatu negara, maka semakin besar pula kemampuan suatu negara dalam melakukan transaksi ekonomi dan keuangan internasional dan semakin kuat nilai suatu mata uang negara tersebut. Kecukupan cadangan devisa menjadi sebuah keharusan suatu negara dengan jumlah harus memenuhi seluruh kebutuhan dan pembiayaan luar negeri serta negara yang bersangkutan.

Dalam pelaksanaan pembangunan, sumber utama pendanaan pembangunan adalah cadangan devisa yang juga merupakan tabungan nasional. Akumulasi cadangan devisa didapatkan dari kegiatan perdagangan internasional baik ekspor maupun impor serta kegiatan arus modal. Selain sebagai sumber pendanaan pembangunan, cadangan devisa juga digunakan sebagai alat transaksi dalam perdagangan internasional. Alat transaksi yang digunakan berupa mata uang kuat yang diterima secara luas sebagai bukti pembayaran internasional. (Yudha, Andy El dan Hadi, 2009). Cadangan devisa negara dapat diperoleh dari kegiatan perdagangan antar negara yang timbul karena adanya keterbatasan dan kelangkaan sumber daya. Cadangan devisa merupakan salah satu jaminan bagi terciptanya stabilitas moneter dan ekonomi makro suatu negara. Semakin giat suatu negara melakukan perdagangan maka semakin banyak pula devisa yang dibutuhkan. (Juliansyah \& Apridar, 2020)

Hal ini dapat mendorong terjadinya perdagangan antar negara yang dikenal dengan kegiatan ekspor dan impor. Apabila suatu negara tidak mampu memenuhi 
kebutuhannya, maka negara tersebut akan melakukan kegiatan impor untuk memenuhi kebutuhan dan negara yang memasok barang tertentu atas negara lain yang membutuhkan akan cenderung melakukan kegiatan ekspor. (Juniantara \& Sri Budhi, 2012)

Perdagangan internasional merupakan pengukuran yang baik di dalam permintaan cadangan devisa. Suatu negara sangat mengharapkan tingkat ekspor yang tinggi, karena kondisi ini akan membuat cadangan devisa akan mengalami peningkatan yang sangat efektif dan efisien. Selain itu cadangan devisa juga dapat digunakan dalam menjaga nilai tukar yang menguntungkan untuk pertumbuhan ekspor.

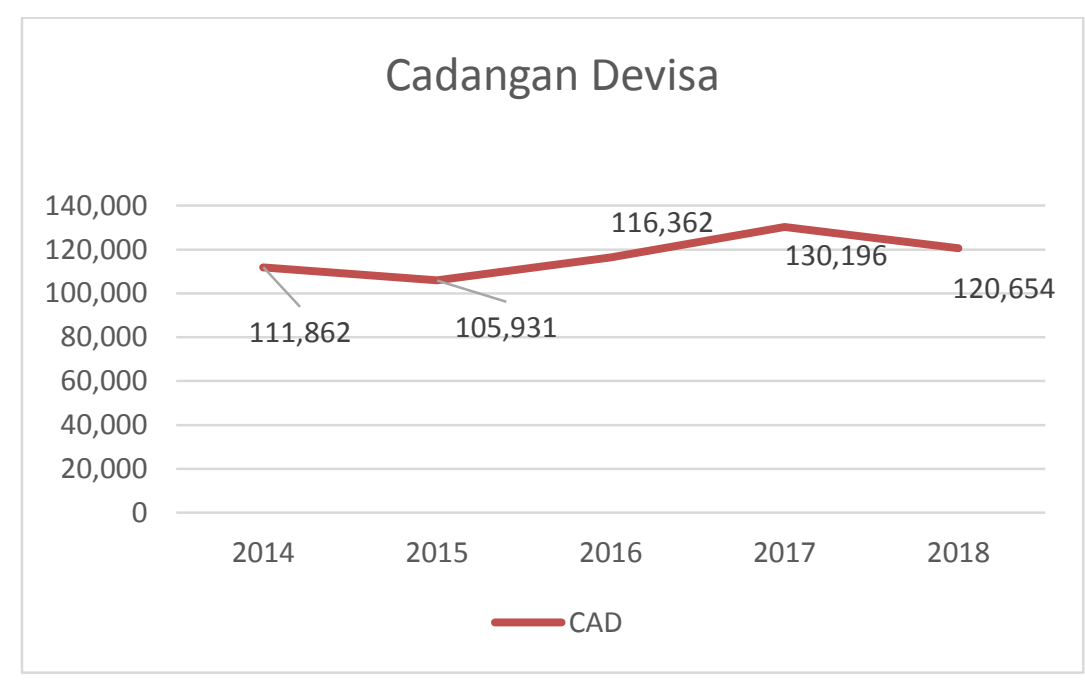

Sumber : Bank Indonesia 2014 - 2018 (diolah)

Gambar 1. Perkembangan Cadangan Devisa Indonesia Tahun 2014 - 2018

Perkembangan cadangan devisa mengalami perkembangan secara fluktuatif. Hal ini dapat dilihat pada gambar 1.1. Tahun 2015, kebijakan rebalancing perekonomian domestik di tengah melambatnya ekonomi global menurunkan pertumbuhan ekonomi di bawah perkiraan. Hal tersebut kemudian memicu terjadinya proses deleveraging yang cepat sehingga menimbulkan gejolak di pasar keuangan, khususnya di pasar saham. Gejolak di pasar keuangan 
menyebabkan terjadinya capital outflows, pelemahan nilai tukar, dan penurunan cadangan devisa yang tajam. Namun di tahun 2016 cadangan devisa mengalami peningkatan hingga tahun 2017, dan di tahun 2018 cadangan devisa menalami penurunan kembali. Tinggi rendahnya posisi cadangan devisa suatu negara dipengaruhi oleh beberapa faktor yaitu produk domestik bruto, ekspor dan kurs.

Produk domestik bruto salah satu ukuran pendapatan nasional untuk ekonomi negara pada periode tertentu (biasanya satu tahun). Proses evaluasi melibatkan jumlah nilai tambah pada setiap tahap produksi dari semua komoditas akhir yang dihasilkan suatu negara dalam jangka waktu tertentu secara moneter (Kira, 2013 dalam Ardianti dan Swara, 2018). (Kuncoro, 2015) menyatakan bahwa Produk Domestik Bruto (PDB) merupakan jumlah nilai barang dan jasa akhir yang dihasilkan oleh seluruh unit ekonomi. PDB atas dasar harga berlaku, atau disebut PDB nominal, menggambarkan nilai tambah barang dan jasa yang dihitung menggunakan harga yang berlaku pada setiap tahun. Sedangkan PDB atas dasar konstan, atau disebut PDB riil, menunjukkan nilai tambah barang dan jasa tersebut yang dihitung menggunakan harga yang berlaku pada satu tahun tertentu sebagai dasar.

Menurut aliran Keynesian dalam penelitian (MASDJOJO, 2010) cadangan devisa dipengaruhi oleh pendapatan nasional, tingkat suku bunga, dan nilai tukar valuta. Pendapatan nasional dapat diartikan sebagai hasil produksi yang mencerminkan nilai dari seluruh masyarakat yang ada suatu negara dalam periode waktu tertentu. Pendapatan nasional mempengaruhi cadangan devisa melalui mekanisme perdagangan Internasional. Berdasarkan penelitian (S \& Zuhroh, 2018) bahwa dalam jangka pendek produk domestik bruto berpengaruh positif dan signifikan terhadap cadangan devisa. Dan dalam jangka panjang, produk domestik bruto berpengaruh positif dan signifikan terhadap cadangan devisa. Pertumbuhan ekonomi yang kuat akan diikuti dengan akumulasi cadangan devisa dan pesatnya peningkatan cadangan devisa merupakan perubahan perekonomian dunia yang 
cukup kompleks (Aizenman, 2008). Menurut aliran Keynesian dalam penelitian (MASDJOJO, 2010) cadangan devisa di pengaruhi oleh Pendapatan nasional, tingkat suku bunga, dan nilai tukar valuta. Pendapatan nasional dapat diartikan sebagai hasil produksi yang mencerminkan nilai dari seluruh produksi nasional yang dihasilkan oleh seluruh masyarakat yang ada suatu negara dalam periode waktu tertentu. Pendapatan nasional mempengaruhi cadanganan devisa melalui mekanisme perdagangan inetransional. (S \& Zuhroh, 2018)

Mengingat pentingnya peran cadangan devisa dalam pembiayaan pembangunan suatu negara, maka setiap negara berusaha untuk mempertahan posisi cadangan devisa yang dimiliki, bahkan berusaha untuk meningkatkannya. Salah satu cara yang dilakukan untuk mempertahankan posisi cadangan devisa yang dimiliki, bahkan berusaha untuk meningkatkannya. Kegiatan perdagangan internasional merupakan salah satu cara yang dilakukan dalam memperoleh tambahan cadangan devisa. Ekspor merupakan salah satu sumber cadangan devisa. Menurut (Mankiw, 2012), ekspor adalah barang dan jasa yang diproduksi di dalam negeri dan di jual ke luar negeri. Kegiatan ekspor yang dilakukan oleh suatu negara supaya mampu bersaing dengan negara-negara lainnya. Ketika suatu negara melakukan ekspor maka negara tersebut akan mendapatkan sejumlah uang dalam bentuk valuta asing yang disebut devisa. Devisa merupakan salah satu dari pendapatan negara. Jika dilihat dari pernyataan tersebut maka dapat dikatakan bahwa jika ekspor meningkat maka cadangan devisa pun meningkat dan sebaliknya. Menurut Sri Wahyuni, 2012 dalam (Sonia \& Setiawina, 2016) menyatakan bahwa jika ekspor menurun maka cadangan devisa yang dimiliki akan turun juga dan sebaliknya apabila tingkat ekspor naik maka cadangan devisa ikut mengalami kenaikan.

Devisa akan berkurang jika tingkat impor lebih besar dibandingkan dengan tingkat ekspor. Semakin besar cadangan devisa di suatu negara maka negara tersebut mampu melakukan kegiatan perdagangan internasional dengan negara lain 
sehingga besar kecilnya akumulasi cadangan devisa suatu negara biasanya akan ditentukan oleh kegiatan perdagangan (ekspor dan impor) serta arus modal negara tersebut. (Gandhi, 2006). Bagi negara berkembang seperti Indonesia ekspor memegang peran penting dalam pembangunan nasional, valuta asing yang didapatkan dari kegiatan ekspor akan menambah cadangan devisa negara yang pada akhirnya dapat memperkuat fundamental makro ekonomi Indonesia. salah satu upaya pemerintah untuk mendapatkan devisa dari luar negeri dengan jalan melakukan pinjaman ke negara lain dan mengekpor hasil-hasil sumber daya alam ke luar negeri. Dari hasil ini maka dapat digunakan untuk menambah dana pembangunan negara. (Juliansyah \& Apridar, 2020)

Hasil penelitian (Dananjaya Baskara, jayawarsa, 2019), bahwa ekspor berpengaruh positif dan signifikan terhadap cadangan devisa Indonesia. Karena apabila nilai ekspor meningkat, maka cadangan devisa akan meningkat. Demikian pula dengan hasil penelitian (Reny, 2014), ekspor berpengaruh signifikan dan positif terhadap cadangan devisa. Apabila Indonesia sering melakukan ekspor barang ke negara lain maka Indonesia akan memperoleh devisa dari negara pengimpor, jadi semakin banyak barang yang diekspor, maka devisa yang akan diperoleh juga semakin banyak. Dengan semakin meningkatnya nilai ekspor, maka menunjukkan bahwa negara tersebut semakin banyak menerima pemasukkan dari negara luar, atau biasa disebut menerima devisa atau valuta asing yang merupakan salah satu sumber pendapatan negara. Hasil penelitian ini sesuai dengan penelitian (Benny, 2013) bahwa jika ekspor meningkat maka jumlah cadangan devisa yang dimiliki akan ikut meningkat sehingga persediaan impor dalam beberapa bulan berikutnya akan tercukupi dan akan memperbesar kemampuan negara tersebut melakukan transaksi ekonomi.

Dalam penelitian (Dani, Sectionna Ceasary Restu, Ismanto, Bambang dan Sitorus, 2020) bahwa kurs berpengaruh secara positif dan signifikan terhadap cadangan devisa. Berpengaruh positif atau peningkatan nilai tukar rupiah akan 
mempengaruhi peningkatan cadangan devisa. Nilai tukar rupiah akan tetap kuat dan cadangan devisa meningkat apabila perekonomian stabil. Demikian pula dalam penelitian (Dananjaya Baskara, jayawarsa, 2019) bahwa kurs nilai tukar rupiah berpengaruh signifikan dan positif terhadap cadangan devisa Indonesia. Karena apabila kurs nilai tukar rupiah menguat terhadap US\$, maka cadangan devisa akan meningkat. Penelitian ini sesui dengan penelitian (Juniantara \& Sri Budhi, 2012) bahwa kurs berpengaruh positif dan signifikan terhadap cadangan devisa. Nilai tukar yang menguat juga dapat menekan laju tingkat inflasi. Apabila harga-harga barnag dan sektor jasa cenderung mengalami kenaikan, atau disebut dengan inflasi, maka akan menyebabkan terlambatnya kegiatan perekonomian di negara bersangkutan. Sehingga negara membutuhkan lebih banyak devisa untuk dapat bertransaksi di luar negara. Oleh sebab itu untuk mencegah makin meningkatnya inflasi maka jumlah mata uang yang beredar harus sesuai dengan kebutuhan, sehingga kebutuhan nilai tukar bisa dijaga.

\section{METODE}

Penelitian yang digunakan dalam penelitian ini berbentuk kuantitatif yang didasarkan pada data kuantitatif dan bersifat asosiatif untuk melihat hubungan antar variabel atau lebih. Obyek penelitian yang digunakan adalah produk domestik bruto, ekspor dan kurs yang merupakan variabel bebas dan cadangan devisa yang merupakan variabel terikat. Jenis data yang digunakan dalam penelitian ini adalah data sekunder yang didapat dari Bank Indonesia, Badan Pusat Statistik (BPS), dan Federal Reserve Bank of St.Louis dalam bentuk data runtun waktu (time series), dengan periode penelitian 2001 - 2018 dan menggunakan E-Views 9.0. Sedangkan teknik pengumpulan data menggunakan teknik dokumentasi melalui pencatatan atau mengcopi data dari Bank Indonesia, Badan Pusat Statistik dan Federal Reserve Bank of St.Louis. Teknik analisis data penelitian ini adalah regresi linier berganda, untuk meneliti pengaruh produk domestik bruto, ekspor dan kurs terhadap cadangan 
devisa Indonesia. Adapun model persamaan regresi linier berganda dalam penelitian ini sebagai berikut :

$\mathrm{CAD}=f(\mathrm{PDB}, \mathrm{X}, \mathrm{E}$,

Dari fungsi tersebut maka dibentuk model ekonometrika sebagai berikut :

$\mathrm{CAD}=\boldsymbol{\beta}_{0}+\boldsymbol{\beta}_{1} P D B+\boldsymbol{\beta}_{2} X+\boldsymbol{\beta}_{3} E+\varepsilon i$

Adanya perbedaan di dalam satuan dan besaran variabel bebas pada persamaan maka persamaan di atas ditransformasikan ke dalam bentuk logaritma natural. Dengan demikian dapat mengetahui koefisien yang menunjukkan elastisitas dan mendekatkan skala data. Logaritma yang digunakan dalam model penelitian ini adalah dalam bentuk log-linier $(\log )$. Maka persamaan menjadi :

$\log (C A D)=\beta_{0}+\beta_{1} \log (P D B)+\beta_{2} \log (X)+\beta_{3}(E)+\varepsilon i$

Dimana :

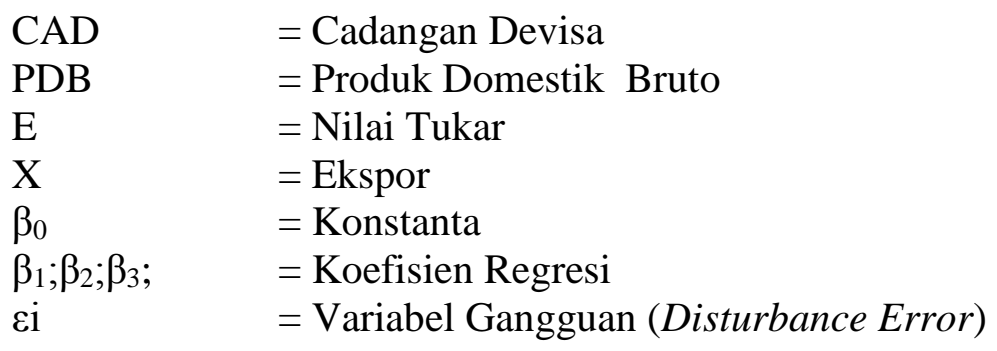

\section{HASIL PENELITIAN DAN PEMBAHASAN}

Uji Asumsi Klasik

Hasil Uji Normalitas

Berdasarkan nilai statistik JB-test dengan angka probability $0.282174>\alpha$ $=0.05$ dapat disimpulkan tidak signifikan, yang berarti menerima hipotesis bahwa residual atau faktor pengganggu mempunyai distribusi normal. 


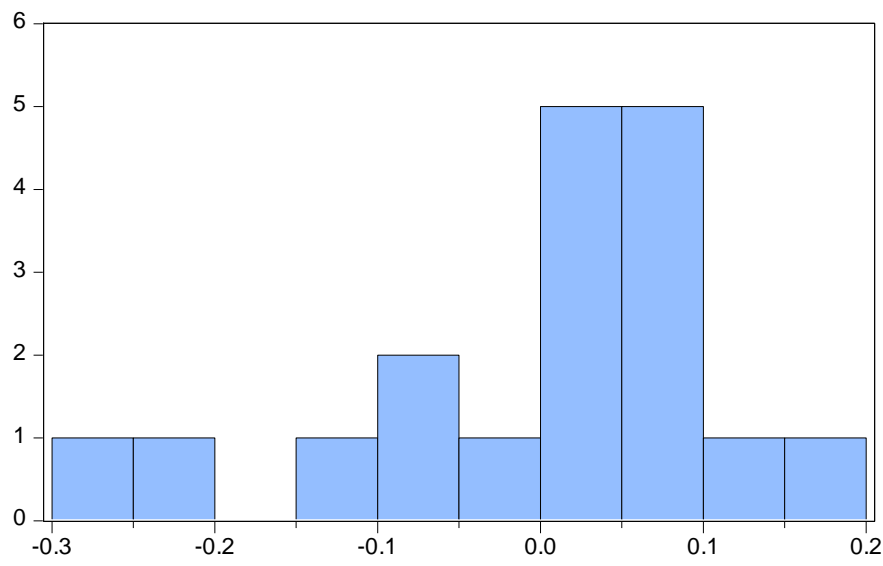

\begin{tabular}{|lc|}
\hline \multicolumn{2}{|l|}{ Series: Residuals } \\
Sample 2001 2018 \\
Observations 18 \\
Mean & $1.27 e-15$ \\
Median & 0.025597 \\
Maximum & 0.180640 \\
Minimum & -0.256966 \\
Std. Dev. & 0.118537 \\
Skewness & -0.914212 \\
Kurtosis & 3.175554 \\
& \\
Jarque-Bera & 2.530466 \\
Probability & 0.282174 \\
\hline
\end{tabular}

Sumber : Eviews 9.0 (data diolah)

Gambar 2. Histogram Uji Normalitas Jarque - Bera (JB-Test)

\section{Hasil Uji Multikolinearitas}

Nilai VIF dari korelasi variabel-variabel bebas tidak ada yang melebihi angka 10. Sehingga dapat disimpulkan antar variabel bebas tidak terjadi multikolinieritas.

Tabel 1. Nilai VIF Dari Hasil Korelasi Antar Variabel Bebas

\begin{tabular}{cccc} 
Variabel & LNPDB & LNX & E \\
\hline LNPDB & 1 & 1.91107 & 1.09205 \\
\hline LNX & 1.91107 & 1 & 1.70306 \\
\hline $\mathrm{E}$ & 1.09205 & 1.70306 & 1 \\
\hline Sumber : Eviews 9.0 (data diolah) & &
\end{tabular}

Tabel 2. Nilai TOL Dari Hasil Korelasi Antar Variabel Bebas

\begin{tabular}{cccc} 
Variabel & LNPDB & LNX & E \\
\hline LNPDB & 1 & 0.52327 & 0.91571 \\
\hline LNX & 0.52327 & 1 & 0.58718 \\
\hline E & 0.91571 & 0.58718 & 1 \\
\hline
\end{tabular}

Sumber : Eviews 9.0 (data diolah)

\section{Hasil Uji Autokorelasi}

Dari hasil empiris uji lagrange multiply (LM-test) yang didapatkan bahwa nilai probabilitas chi-squares sebesar 0.4509 lebih besar dari nilai $\alpha=0.05$. Dengan 
demikian hipotesis nol (H0) tidak dapat ditolak. Dapat dikatakan bahwa modal tidak mengandung autokorelasi.

Tabel 3. Hasil Uji Autokorelasi Dengan LM-Test

Breusch-Godfrey Serial Correlation LM Test:

\begin{tabular}{llll} 
F-statistic & 0.582509 & Prob. F $(2,12)$ & 0.5735 \\
\hline Obs*R-squared & 1.592882 & Prob. Chi-Square(2) & 0.4509
\end{tabular}

Sumber : Eviews 9.0 (data diolah)

\section{Hasil Uji Hipotesis}

\section{Uji Simultan (Uji F)}

Hasil estimasi dapat diketahui bahwa nilai F statistik sebesar 96.04177 dengan probabilitas statistik sebesar 0.00000 lebih kecil dari $\alpha=0.05$ yang menunjukkan bahwa secara bersama-sama (uji serempak) semua variabel independent yaitu produk domestik bruto, kurs dan ekspor memiliki pengaruh yang nyata terhadap cadangan devisa di Indonesia.

Tabel 4. Hasil Analisis Regresi

\begin{tabular}{lllll} 
Variabel & Koefisien & Std. Error & t-statistik & Prob \\
\hline Constant & -2.270749 & 0.874226 & -2.597440 & 0.0211 \\
\hline LNPDB & 0.268458 & 0.058434 & 4.594175 & 0.0004 \\
\hline LNX & 0.695454 & 0.129803 & 5.357768 & 0.0001 \\
\hline $\mathrm{E}$ & 0.013882 & 0.005743 & 2.417286 & 0.0299 \\
\hline \multicolumn{5}{c}{ F-statistik $=96.04177$} \\
\hline LNCAD = - 2.270749+0.268458*LNPDB + 0.695454*LNX + 0.013882*E \\
\hline $\mathrm{R}^{2}=0.953662$ & DW $=1.413393$ & 0.000000
\end{tabular}

Sumber : Diolah dari data penelitian periode $2001-2018$

Hasil pengujian secara parsial dapat dilihat pada tabel estimasi yang diperoleh melalui uji $\mathrm{t}$ dengan tingkat signifikan $\alpha=5$ persen. Dari hasil perhitungan diperoleh koefisien produk domestik bruto sebesar 0.268458 , nilai thitung 4.594175 dengan probabilitas untuk variabel produk domestik bruto sebesar 
prob $=0.0004$. Ini menunjukkan bahwa variabel produk domestik bruto berpengaruh positif dan signifikan mempengaruhi terhadap cadangan devisa di Indonesia. Ini menunjukkan setiap peningkatan 1 persen produk domestik bruto akan meningkatkan cadangan devisa sebesar 0.268458 persen.

Koefisien variabel ekspor sebesar 0.695454, nilai t-hitung 5.357768 dan probabilitas $=0.0001$ menunjukkan bahwa variabel ekspor berpengaruh positif dan signifikan mempengaruhi cadangan devisa di Indonesia. Ini menunjukkan setiap peningkatan 1 persen ekspor akan meningkatkan cadangan devisa sebesar 0.695454 persen. Koefisien variabel nilai tukar rupiah sebesar 0.013882 dengan nilai t-hitung 2.417286 dengan probabilitas $=0.0299$ menunjukkan bahwa variabel nilai tukar rupiah berpengaruh positif dan signifikan mempengaruhi terhadap cadangan devisa di Indonesia. Ini menunjukkan setiap peningkatan $1 \%$ kurs akan meningkatkan cadangan devisa sebesar 0.013882 persen.

\section{Koefisien Determinasi $\left(\mathbf{R}^{2}\right)$}

Nilai R-squared sebesar 95.36 memberikan arti bahwa sebesar 95.36\% variasi variabel cadangan devisa yang dapat dijelaskan oleh variabel produk domestik bruto, kurs dan ekspor, sedangkan sisanya $4.64 \%$ dijelaskan oleh variabel lain yang tidak diteliti di dalam model penelitian ini.

\section{Pengaruh PDB terhadap Cadangan Devisa}

Dari hasil output regresi diperoleh hasil koefisien estimasi PDB sebesar 0.0001, menunjukkan bahwa PDB berpengaruh positif dan signifikan terhadap cadangan devisa di Indonesia. Hasil penelitian ini sesuai dengan penelitian Dianita dan Zuhroh (2018) bahwa dalam jangka pendek produk domestik bruto berpengaruh positif dan signifikan terhadap cadangan devisa Indonesia. Dan bahwa dalam jangka panjang produk domestik bruto berpengaruh positif dan signifikan terhadap cadangan devisa Indonesia.

\section{Pengaruh Ekspor terhadap Cadangan Devisa}


Dari hasil output regresi diperoleh hasil koefisien estimasi Ekspor sebesar 0.0001, menunjukkan bahwa Ekspor berpengaruh positif dan signifikan terhadap cadangan devisa di Indonesia. Hal ini sejalan dengan penelitian Mahmudah (2019) bahwa ekspor berpengaruh positif dan signifikan terhadap cadangan devisa. Jika ekspor meningkat maka jumlah cadangan devisa yang dimiliki akan ikut meningkat sehingga persediaan impor dalam beberapa bulan berikutnya akan tercukupi dan akan memperbesar kemampuan negara tersebut melakukan transaksi ekonomi.

\section{Pengaruh Nilai Tukar terhadap Cadangan Devisa}

Dari hasil output regresi diperoleh hasil koefisien estimasi Kurs sebesar 0.0225 , menunjukkan bahwa Kurs berpengaruh positif dan signifikan terhadap cadangan devisa di Indonesia. Hasil penelitian ini sejalan dengan penelitian Lestari dan Swara (2016), kurs berpengaruh positif dan signifikan terhadap cadangan devisa. Demikian pula dengan penelitian Juniantara dan Budhi (2012), bahwa kurs berpengaruh positif dan signifikan terhadap cadangan devisa.

\section{KESIMPULAN}

Berdasarkan hasil analisis, maka dapat disimpulkan bahwa variabel produk domestik bruto, ekspor dan kurs berpengaruh positif dan signifikan terhadap cadangan devisa Indonesia.

\section{DAFTAR RUJUKAN}

Aizenman, J. (2008). Large hoarding of international reserves and the emerging global economic architecture. Manchester School, 76(5), 487-503. https://doi.org/10.1111/j.1467-9957.2008.01072.x

Benny, J. (2013). Ekspor Dan Impor Pengaruhnya Terhadap Posisi Cadangan Devisa Di Indonesia. Jurnal Riset Ekonomi, Manajemen, Bisnis Dan Akuntansi, 1(4), 1406-1415.

Dananjaya Baskara, jayawarsa, P. S. (2019). Pengaruh Ekspor, Impor, Kurs Nilai Tukar Rupian, Dan Tingkat Inflasi Terhadap Cadangan Devisa Indonesia Periode 1999-2018. Warmadewa Economic Development Journal, 2(2), 6471. 
Dani, Sectionna Ceasary Restu, Ismanto, Bambang dan Sitorus, D. S. (2020). Pengaruh Ekspor Impor dan Nilai Tukar Rupiah Terhadap Cadangan Devisa Indonesia Tahun 2000 - 2019. Jurnal Ecodunamika, 3(2).

Gandhi, D. V. (2006). Pengelolaan Cadangan Devisa di Bank Indonesia. In Seri Kebanksentralan (Issue 03).

Juliansyah, H., \& Apridar, P. M. (2020). Analisis Faktor-faktor Yang Mempengaruhui Cadangan Devisa Indonesia Bukti (Kointegrasi dan Kausalitas). 3, 32-46.

Juniantara, I., \& Sri Budhi, M. (2012). Pengaruh Ekspor, Impor Dan Kurs Terhadap Cadangan Devisa Nasional Periode 1999-2010. E-Jurnal Ekonomi Pembangunan Universitas Udayana, $\quad 1(1), \quad 32-$ $38 .{ }^{\prime}$

Kuncoro, M. (2015). Mudah Memahami dan Menganalisis Indikator Ekonomi (2nd ed.). UPP STIM YKPN.

Mankiw, N. G. (2012). Pengantar Ekonomi Makro. Salemba Empat.

MASDJOJO, G. N. (2010). Kajian Pendekatan Keynesian Dan Monetaris Terhadap Dinamika Cadangan Devisa Melalui Penelusuran Neraca Pembayaran Internasional: Studi Empiris Di Indonesia Periode 1983-2008. Universitas Diponegoro, $1-398$. http://eprints.undip.ac.id/24004/1/GREGORIUS_NASIANSENUS_MASDJ OJO.pdf

Reny, A. (2014). Pengaruh Ekspor, Impor, Nilai Tukar Rupiah, Dan Tingkat Inflasi Terhadap Cadangan Devisa Indonesia. Jurnal Wira Ekonomi Mikroskil, 4(2), 61-70. https://www.mikroskil.ac.id/ejurnal/index.php/jwem/article/view/214/137

S, D. D., \& Zuhroh, I. (2018). Analisa Cadangan Devisa Indonesia Tahun 19902016. Jurnal Ilmu Ekonomi, 2(1), 119-131.

Sonia, A. P., \& Setiawina, N. D. (2016). Pengaruh Kurs, Jub Dan Tingkat Inflasi Terhadap Ekspor, Impor Dan Cadangan Devisa Indonesia. E-Jurnal Ekonomi Pembangunan Universitas Udayana, 5(10), 1077-1102.

Sukirno, S. (2010). Makroekonomi Teori Pengantar. PT Raja Grafindo.

Yudha, Andy El dan Hadi, S. (2009). Analisis Pengaruh Tingkat Suku Bunga SBI Dan Volume Ekspor Impor Terhadap Nilai Tukar Rupiah. Jurnal Ekonomi Pembangunan, 7(1). 